\title{
Importance of Scientifically Based Facts in Crisis Communication: Evidence from Earthquakes in Zagreb and Petrinja
}

Izidora Marković Vukadin Institute for Tourism, Zagreb, Croatia e-mail: izidora.markovic@iztzg.hr

Marija Mustá́

University of Zagreb, Faculty of Science, Department of Geophysics, Seismological Survey, Croatia e-mail: marija.mustac@gfz.hr

Lidija Nujić

Institute for Tourism, Zagreb, Croatia

e-mail: lidija.nujic@iztzg.hr

Karmen Fio Firi

University of Zagreb, Faculty of Science, Department of Geology, Croatia

e-mail: karmen.fio@geol.pmf.unizg.hr

Jasminka Martinjak

Croatian Geological Survey, Zagreb, Croatia

e-mail: jasminka.martinjak@hgi-cgs.hr

\section{Zrinka Marušić}

Institute for Tourism, Zagreb, Croatia

e-mail: zrinka.marusic@iztzg.hr

\section{Maja Baniček}

University of Zagreb, Faculty of Civil Engineering, Croatia

e-mail:maja.banicek@grad.unizg.hr

ABSTRACT Earthquakes are natural phenomena that can strongly affect the human population, infrastructure, and the environment. Croatia is part of a tectonically and seismically active area so its habitants and relevant institutions should be aware of possible hazardous events, which can be devastating. Therefore, crisis communication is extremely important, and in the event of natural disasters such as earthquakes, it must be clear, timely and concise. Scientific institutions dealing with earthquakes should also be involved in crisis communication. The information on two strong earthquakes in 2020 that shocked the area of Zagreb and Petrinja and the wide surrounding area, have shown how relevant institutions can deal with information on earthquakes and their consequences and share them publicly. This paper adopts a mixedmethods research design, combining both qualitative, and quantitative data on the Zagreb and 
Petrinja earthquakes from various sources of scientific and professional institutions in the field of geology, geophysics, seismology and civil engineering in Croatia. Empirical data suggest that interactive communication that strives to address local contextual concerns, explain actions, and provide honest, timely, accurate and reliable information is most effective. In the future, institutions have to find a way to react or share their information to help in the crisis.

Key words: earthquakes, social media, content analysis, crisis communication.

\section{Introduction}

Earthquakes are the shaking of the Earth's surface that results from seismic waves created in a sudden release of elastic energy in the Earth's lithosphere. These natural phenomena can strongly affect the human population, infrastructure, and the environment. Their consequences can be devastating, especially in areas where buildings are not adequately constructed and where the public is not educated about the possibility of earthquake occurrence, and trained to avoid earthquake-related risks. Therefore, we must be aware that earthquakes can happen, especially in areas where they were previously noted, and be prepared to react with as little panic and fear as possible.

On $22^{\text {nd }}$ of March 2020, a local magnitude $\left(M_{L}\right) 5.5$ earthquake shocked Zagreb, the capital of Croatia, the neighbouring counties, and was felt even in the surrounding countries. Nine months later, on $29^{\text {th }}$ of December 2020, an even stronger earthquake of $M_{L} 6.2$ struck central Croatia. Its epicentre was between Petrinja and Glina, approximately $50 \mathrm{~km}$ from Zagreb. In these two natural disasters, the number of casualties was relatively low ( 8 in total), but the number of damaged buildings and evacuated people was counted in tens of thousands. The estimated damages and losses for both events are more than 15 billion euros. These two events can be described as crisis events affecting an extremely large number of people.

According to Lerbinger (1997), there are three categories of crisis: crises of the physical world (natural disasters and catastrophes such as landslides, tornados, tidal waves, storms, floods and earthquakes); crises of the human climate and crises of management failure. Natural disasters "present an extraordinary difficult context for inter-organizational and inter-jurisdictional coordination” (Sellnow, 2011). They also require immediate responses from multiple organizations that typically do not communicate with each other to achieve the common goal of alleviating threats to a community. Natural disasters, including earthquakes, have a strong impact on the safety of individuals (Becker et al., 2012). Therefore, reporting at the right moment with the aim of saving lives is extremely important.

Earthquake crisis communication is significantly underestimated in Europe. An exception of good communication and crisis responses is related to the L'Aquila earthquake (Italy) in 2009, with a significant number of papers dealing with communication 
channels (Alexander, 2010; Marincioni et al., 2012; Sellnow et al., 2017; Benassia \& Marchi, 2017). Furthermore, very few papers even on the global level deal with this topic (Chen, 2009; Acar/Muraki, 2011; Cho et al., 2013; Seyle, 2013, Tekeli-Yesil et al., 2019). The emphasis is on official government communication channels (Boing, 2006), which have the priority role of saving lives and reducing property damage. Even though the secondary goal of communication is to increase public safety and understanding of the current situation (Fraser, 2004), scientific institutions are commonly not recognized as important stakeholders in crisis communication, despite confidence in their knowledge (Cheng, 2009). On the contrary, in the case of the 2009 earthquake in Italy, scientists were accused of allegedly giving out misleading and incorrect information to the public before the earthquake on $6^{\text {th }}$ of April 2009 (Alexander, 2014; Benasia \& Marchi, 2017). However, crisis communication of scientifically based facts through the official channels of scientific institutions can positively impact crisis behaviour of the general population (Chen, 2009). Our review of scientific papers on the topic of crisis communication of scientific facts in times of natural disasters should give clues on how to (better) react in this type of situation in the future.

Strong earthquakes, such as the Zagreb and Petrinja 2020 earthquakes, are extreme geohazards with unpredictable timing, that require a rapid response from all stakeholders. The main objective of this paper is to analyse the communication modalities (content and frequency of visits) of scientific and professional institutions in the field of geology, geophysics, seismology and civil engineering in Croatia during and after two massive earthquakes in the Zagreb and Petrinja area.

\section{Communication in time of natural crisis}

A crisis is an unexpectedand unwanted process that lasts for a certain period of time, which can be alleviatedonly partially and can end in different ways (Mirosavljević, 2008). It is a serious incident that endangers the safety of people, environment and products, and can be caused by human activities and by natural disasters. Also, it is possible to distinguish internal and external crises, depending on where they happen. In periods of natural disasters, the importance of scientifically based facts in crisis communications is strongly emphasized. In analysing the impact of scientific facts, the largest number of papers is committed to weather disasters, especially hurricanes (Spence et al., 2007; Garnett and Kouzmin, 2007; Patric et al., 2015; Spence et al., 2015; Sadri et al., 2018; Lachlan et al., 2019)

To understand the disjuncture between practices that are adopted to mitigate perceived risks and those that are not has been one of the primary focuses within the natural hazards field (Whyte, 1986; Mileti, 1994). Much of the focus of this effort has been on helping individuals and communities to be better prepared for a particular hazard. Efficient communication of scientific facts is often detected as a key practice 
to move toward the desired goal - more disaster resilient communities (Steelman and McCaffrey, 2013) Furthermore, it is important to connect risk management and crisis communications which are inseparable. Communication has often been seen at the center of improved response during the disaster management cycle. Disaster management cycle is in essence a process by which governments, businesses, and civil society plan for and diminish the impact of disasters, react during and immediately following a disaster, and take steps to recuperate after a disaster has happened (Sawalha, 2020). Risk communication and crisis communication focus on separate points in the disaster management cycle (Steelman and McCaffrey, 2013). It was revealed that, in some cases, through time-series relevant scientific information became less prevalent as the crisis moved from the prodromal to acute phase, and information concerning specific remedial behaviors was absent (Patric et al., 2015)

Risk management theory also points out that crisis teams are composed of diverse combinations of emergency management personnel, health specialists, scientific experts and others. Among these teams and through their interactions with other networks involved in the crisis, interorganizational networking also occurs (Garnett and Kouzmin, 2007). Traditionally associated with environmental management, public health, and emergency management traditions, risk communication strives to inform people about a possible future harm and the associated dangers so that they might take the risk mitigation measures through science based procedures (Seeger et al., 2003; Seeger 2006). To understand how natural disasters can be managed through crisis communication, crisis communication framework is going to be described.

\section{Crisis communication framework}

In its broadest conception, crisis communication is any communication under the state of crisis, which is distinct from normal communication by individual organizations. Crisis communication could be viewed as the "methods and policies used by a corporation for the distribution of information during an uncomfortable situation affecting the public" (Cutlip et al., 2003). In order to maximise effectiveness, gain authority amongst an audience and continue to communicate regularly throughout the lifespan of an event, it should begin as soon as possible (Collins et al., 2016). Crisis communication can perform three functions: instructive information, which informs people on how to react regarding personal protection; adjustive information, which helps people to deal with uncertainty; and internalizing information, which refers to information that helps an organization administer its reputation (Sturges, 1994).

Credible crisis communication begins with understanding how to properly structure and deliver emergency messages. The language used by a crisis communication team should address both the stage and seriousness of the situation; during a low-intensity event, crisis communication should be informative, distinct and clear but not aggressive and pushy in order to avoid inducing panic in the public, and as the severity becomes 
stronger, direct public health recommendations should be delivered in clear, regular intervals via media. Messages should empower groups and individuals to take positive action to help reaffirm a sense of crisis control (Collins et al., 2016). To present the right information as soon as possible, within 24 hours from the moment of the crisis is the most important point for every crisis situation, from the company's point of view (Puška et al., 2014:94). Without information, people often create a picture of the situation themselves - which can be incorrect and favour the development of public opinion in the wrong direction. Rather than passively waiting for the situation to develop, it is necessary to be proactive and communicate in organization's favour. It is necessary to maintain information security, to provide access to information, the communication process should be directed, diverse adequate communication channels should be used, as well as accessibility to all media, public and employees, and connection with them should be maintained. Information has to travel fast, and has to be accurate and specific, with the minimum of irrelevant supporting information (Bulajić, 2010).

Collins et al. (2016:162) have gathered the guidelines on best practice principles for risk communication:

- Reduce inappropriate public actions (rioting, looting or overwhelming infrastructure).

- Deliver clear and consistent messages across all media (news and social media).

- Ensure that selected media channels are diverse enough to reach the widest population, including minorities and marginalised groups.

- Be regular to reduce the formation of rumours or inaccurate information getting out from unofficial sources or social networks.

- Empower the public and responders to make better decisions.

- Be accurate and reflect the exact level of risk, don't be too extreme or too casual in communication of seriousness of situation.

- Be flexible enough to fit every scenario.

Listening to feedback, adjusting the message and provoking an audience into action can help in solving all stages of the disaster/emergency management cycle (Collins et al., 2016:162). Coombs (2014:6) has presented the best research-based evidence from crisis communication research:

- If possible, publish the information about a crisis before it is reported in traditional or digital media.

- Report information about a crisis on the organization's online communication channels.

- Whenever there are victims or potential victims, immediately tell people how to physically protect themselves from the crisis, and immediately provide them with information and actions designed to help them cope mentally with the crisis (this includes details about the crisis event, expressions of sympathy, corrective action, and counselling). 
- Organizations recover reputations and stock prices quicker when they communicate frequently and through many channels, than when they release very little information.

- Denial should only be used when an organization faces a rumour or misinformation about the crisis.

Puška and Maksimović (2014:94) suggest:

- The public should come first.

- Organizations should take responsibility to solve the problem.

- Organizations should have an honest relationship with the stakeholders - without concealing facts and trying to deceive.

- Never say "No comment".

- Appoint one spokesperson.

- Organize a central information centre.

- Constantly provide information- when information is withheld or hidden, it becomes news in itself.

- Get acquainted with the needs and deadlines of the media.

- Be available.

- Supervise news and telephone inquiries coverage.

- Have an active communication with key public groups.

In the past, people generally relied on the mainstream media for information during crises because they could obtain clues and information about safety and welfare of their acquaintances' only through the news, regardless of their access to telephone services, and could share emotional support indirectly (Perez-Lugo, 2004). The emergence of social media has answered the public's need for personal and direct communication as well as for information about their safety and welfare during crises. Although people still rely partly on the mainstream media to acquire crisis information, gradually they have increased their reliance on social media such as Twitter and Facebook (Cho et al., 2013:30).

\section{Current scientific findings about earthquakes in Zagreb and Petrinja}

Croatia is part of a tectonically and seismically active area, due to a constant thrusting of the Adriatic microplate under the Euroasian tectonic plate in the boundary zone between the African and Euroasian tectonic plates (Ivančić et al., 2018). These movements are present in the whole Mediterranean, with a velocity up to $5 \mathrm{~mm} /$ year in the Croatian part (McClusky et al., 2000; Weber et al., 2010). Seismic activity in Croatia is most pronounced in three areas: coastal and hinterland part of Dalmatia, northern part of the Adriatic coast between Ilirska Bistrica in Slovenia and the city of Senj, and in northwestern Croatia (Herak et al., 2011, Croatian Standards Institute, 2011). 
The most known and devastating earthquakes noted in the last 400 years include magnitudes (M) estimated to be between 5.1 and 7.1 (Dasović et al., 2020), with the strongest one being the 1667 Dubrovnik earthquake, which had a devastating effect on the city of Dubrovnik and marked the end of the Dubrovnik Republic. Earthquakes from the end of the 19th century in Klana near Rijeka (1870, M 5.5) and in Zagreb (1880, M 6.2) brought the awareness about earthquakes and enabled their scientific exploration in our part of the world. The research culminated with a significant geophysical discovery of Andrija Mohorovičić on the discontinuity between the Earth's crust and the upper mantle, after an M 5.8 earthquake struck the Pokupsko area in 1909 (Mohorovičić, 1910).

Strong earthquakes in 2020 once again reminded the general public about seismic activity in our area. The first earthquake series, with a $\mathrm{M}_{\mathrm{L}} 5.5$ and subsequent $\mathrm{M}_{\mathrm{L}}$ 5.0 earthquake on March $22^{\text {nd }} 2020$, which occurred during the first COVID-19 lockdown, affected the wider area of the City of Zagreb, caused significant material damage and one human victim (Bogdan, 2020). The details about the earthquake and its effects and consequences are described in Dasović et al. (2020), Šavor Novak et al. (2020) and Herak et al. (2021). The second series started on December $28^{\text {th }} 2020$ in the wider area of the Petrinja city with a $\mathrm{M}_{\mathrm{L}} 5.0$ earthquake, which was followed by a much stronger event of $M_{L} 6.2$ on December $29^{\text {th }}$. These strong quakes were largely felt in all parts of Croatia, as well as in the surrounding countries. Material damage after the largest earthquakes and still ongoing aftershock sequence has been enormous, with seven people losing their lives during the main strike.

Geophysicists (especially seismologists), geologists, civil engineers, and everybody that could help and contribute to the understanding of the earthquakes and possible subsequent events immediately started with the research and provided information to the general public to prevent the spread of fear and false information. The first information about the earthquakes were given by the Seismological Survey and the Department of Geophysics of the Faculty of Science in Zagreb. Their information was regularly released by the media (TV, radio, Internet, newspapers). Further steps included data collection and interpretation which enabled publishing papers in several scientific (Markušić et al., 2020) and popular magazines (Bogdan, 2020; Dasović et al., 2020).

\section{Methodology}

A mixed-methods research design was adopted to analyse both qualitative and quantitative data from various sources in order to gain close insight into virtual information's activity during the crisis communication following the Zagreb and Petrinja earthquakes (Table 1.) 
Table 1.

Research design

\begin{tabular}{|c|c|c|}
\hline & Qualitative research approach & Quantitative research approach \\
\hline $\operatorname{Aim}(s)$ & $\begin{array}{l}\text { To gain insight into the characteristics of } \\
\text { crisis communication of the scientific and } \\
\text { professional institutions' communication } \\
\text { channels. } \\
\text { To assess and classify the content available } \\
\text { on those communication channels. }\end{array}$ & $\begin{array}{l}\text { To analyse the difference in frequency of } \\
\text { visits to the Facebook pages of the analysed } \\
\text { institutions before and after the earthquake }\end{array}$ \\
\hline Method & $\begin{array}{l}\text { Content analysis according to the following } \\
\text { target groups: general population, media, } \\
\text { and academic community. }\end{array}$ & Descriptive analysis \\
\hline Period & $\begin{array}{l}\text { 1. March } 22^{\text {nd }}-\text { April } 22^{\text {nd }}, 2020 \\
\text { 2. December } 28^{\text {th }}, 2020-\text { January } 29^{\text {th }} \text {, } \\
2021\end{array}$ & $\begin{array}{l}\text { 1. February, } 21^{\text {st }}-\text { March } 21^{\text {st }}, 2020 \\
\text { (before the earthquake) } \\
\text { 2. March } 22^{\text {nd }}, 2020-\text { April } 22^{\text {nd }}, 2020 \\
\text { (after) } \\
\text { 3. November } 27^{\text {th }}, 2020-\text { December } 27^{\text {th }} \text {, } \\
2020 \text { (before) } \\
\text { 4. December } 28^{\text {th }}, 2020-\text { January } 29^{\text {th }}, \\
2021 \text { (after) }\end{array}$ \\
\hline $\begin{array}{l}\text { Data sources } \\
\text { (communication } \\
\text { channels) }\end{array}$ & $\begin{array}{l}\text { Websites, Twitter, Facebook group and } \\
\text { Facebook pages }\end{array}$ & $\begin{array}{l}\text { Facebook pages, websites with Google } \\
\text { Analytics data available }\end{array}$ \\
\hline $\begin{array}{l}\text { Data owners } \\
\text { (institutions) }\end{array}$ & $\begin{array}{l}\text { University of Zagreb: } \\
\text { Faculty of Science: } \\
\text { - Department of Geophysics } \\
\text { - Department of Geology } \\
\text { Faculty of Mining, Geology and } \\
\text { Petroleum Engineering } \\
\text { Croatian Center for Earthquake } \\
\text { Engineering; } \\
\text { Croatian Geological Survey } \\
\text { Croatian Geological Society }\end{array}$ & $\begin{array}{l}\text { University of Zagreb: } \\
\text { Faculty of Science, Department of } \\
\text { Geophysics } \\
\text { Faculty of Mining, Geology and } \\
\text { Petroleum Engineering } \\
\text { Croatian Geological Survey } \\
\text { Croatian Geological Society } \\
\text { Croatian Center for Earthquake Engineering }\end{array}$ \\
\hline
\end{tabular}

Quantitative research (descriptive statistics) was applied to analyse the frequency of virtual visits to official web pages and Facebook pages/groups. The analysis of the web pages included those pages only, for which Google Analytics data had been available at the time (the Croatian Geological Survey, Faculty of Mining, Geology and Petroleum Engineering from the University of Zagreb and the Croatian Geological Society). Facebook visitation data was obtained and analysed for all listed institutions. The frequencies of visits to the official web pages and Facebook pages/groups are presented graphically for the two periods - before and after the earthquake, separately for the Zagreb and Petrinja earthquake. 
Content analysis was used as a qualitative data analysis approach. The aim of the content analysis was to classify the content and gain insight into the characteristics of crisis communication of the scientific and professional institutions, supported by relevant literature, to show the potential challenges and opportunities in crisis communication during an earthquake. The content analysis was applied on the content published on the social media channels and websites of the following institutions: University of Zagreb, Faculty of Science, Department of Geophysics (website, Twitter, Facebook group and Facebook page), and Department of Geology (website, Facebook profile), Croatian Geological Survey (website, Facebook page), Croatian Geological Society (website, Facebook page), Faculty of Mining, Geology and Petroleum Engineering in Zagreb (website, Facebook page), and Croatian Center for Earthquake Engineering (website, Facebook page). The unit of the analysis was a published post on social media channels and/or the websites of the above mentioned institutions, during the two time periods corresponding to the Zagreb and Petrinja earthquakes, respectively: (i) between March $22^{\text {nd }}$ and April 22 ${ }^{\text {nd }}, 2020$, and (ii) between December $28^{\text {th }}, 2020$ and January $29^{\text {th }}, 2021$. A total of 600 published posts on the institutions' social media, and 34 posts on their websites were collected and analysed.

The content analysis was performed from February $22^{\text {nd }}$ to March $7^{\text {th }}$, 2021. Following the review of all the content, it was classified according to target audience criteria, and the content topic criteria. The content communicated on these channels was categorized according to the target audience it primarily addresses into the following three main groups: (i) content for the general population, (ii) content for the media, and (iii) content for the academic community.

In accordance with the paper objectives, the content was classified according to the topic criteria into the following groups:

- Official report (press release) and / or more detailed explanation of the event (which is also published on the website).

- Useful information (how to behave, how to physically protect yourself, how to psychologically protect yourself, posts aimed to reduce panic in the general public).

- Additional information (preliminary reports on the epicenter, magnitude and intensity of subsequent earthquakes, activities performed on the field, shared media articles).

- Portals whose topic is the earthquake in Zagreb or Petrinja that contain accurate and useful information, citizen experiences and photos.

- Other content unrelated to the earthquakes in Zagreb or Petrinja.

Attention has been paid to the date of publication as well. Finally, two independent researchers reviewed the content published through the mentioned channels and 
evaluated whether the institutions communicated the content in line with the recommendations on crisis communication from literature. In a case of disagreement, the content was re-evaluated until an agreement was reached.

\section{Quantitative research results and discussion}

\section{Website traffic - The Zagreb earthquake}

All the mentioned sites in the period before the earthquake had some average attendance, without any special peaks observed. As expected, in the post-earthquake period, all sites recorded higher traffic. It should also be noted that not all of the sites published an official statement about the earthquake. In this period only the Croatian Geological Survey published one (Fig. 1). The most obvious increase in the number of visits can be seen for the Croatian Geological Survey website with an increase of 925\% compared to the previous day, while the RGNF website had a constantly higher number of visitors, primarily due to regular content for its students.

Figure 1.

Number of visits to selected websites before and after the Zagreb earthquake

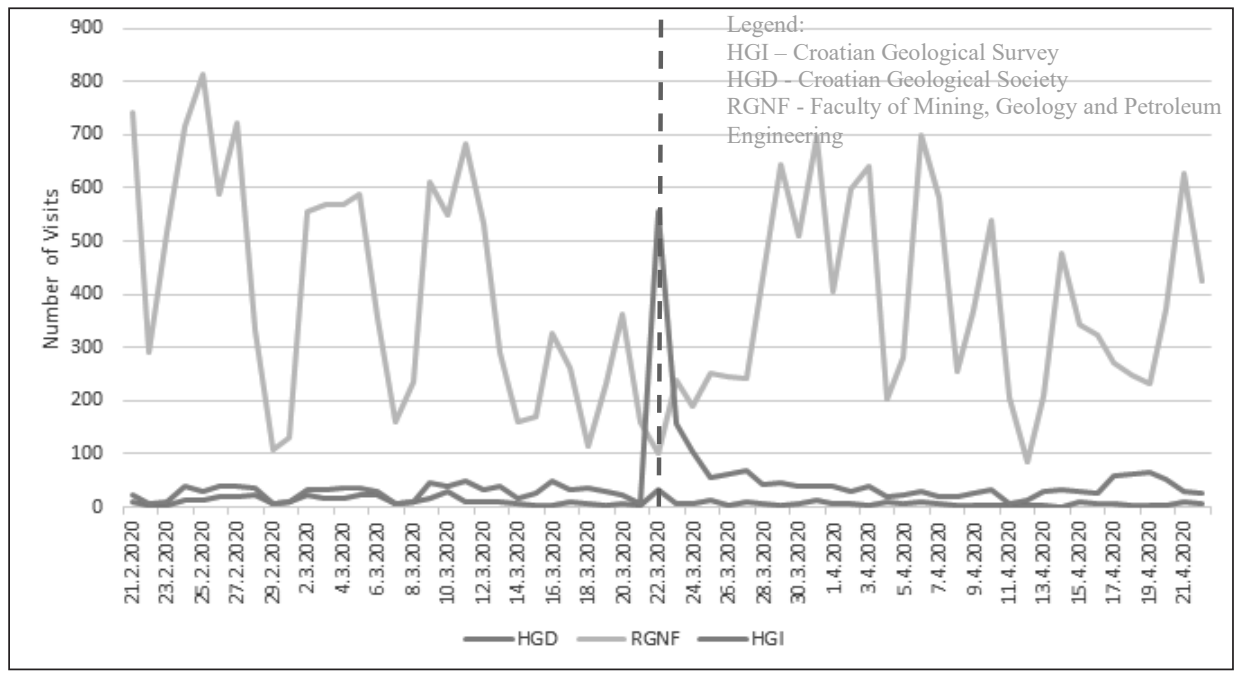

\section{Website traffic - The Petrinja earthquake}

Similar to the Zagreb earthquake, in the period before the Petrinja earthquake, all sites had recorded regular traffic without significant peaks observed (Fig. 2). After the earthquake itself, traffic on all analysed websites increased significantly. All pages were late with the official announcement of the earthquake, with (HGI) having the earliest announcement that was mostly shared on other pages. The number of visits to 
the pages is, of course, the highest in the days of the publication of official announcements. According to the analysis of these pages, we can conclude that the higher traffic is directly related to the official announcements of individual institutions. Therefore, attention should be paid to the clearly stated information regarding the content of such announcements, as well as their timely publication.

The analysis of the Facebook pages clearly shows that in the case of both earthquakes, the frequency of daily visits increased exceptionally in the days of the earthquakes, especially to the Department of Geophysics. This is expected, especially in the case of the Zagreb earthquake, which was an unprecedented event in the age of modern communications in the Republic of Croatia. Other institutions have only had a slightly increased number of visits (Fig. 2)

Figure 2.

Number of visits to Facebook pages of relevant institutions in the month before, and after the Zagreb earthquake.

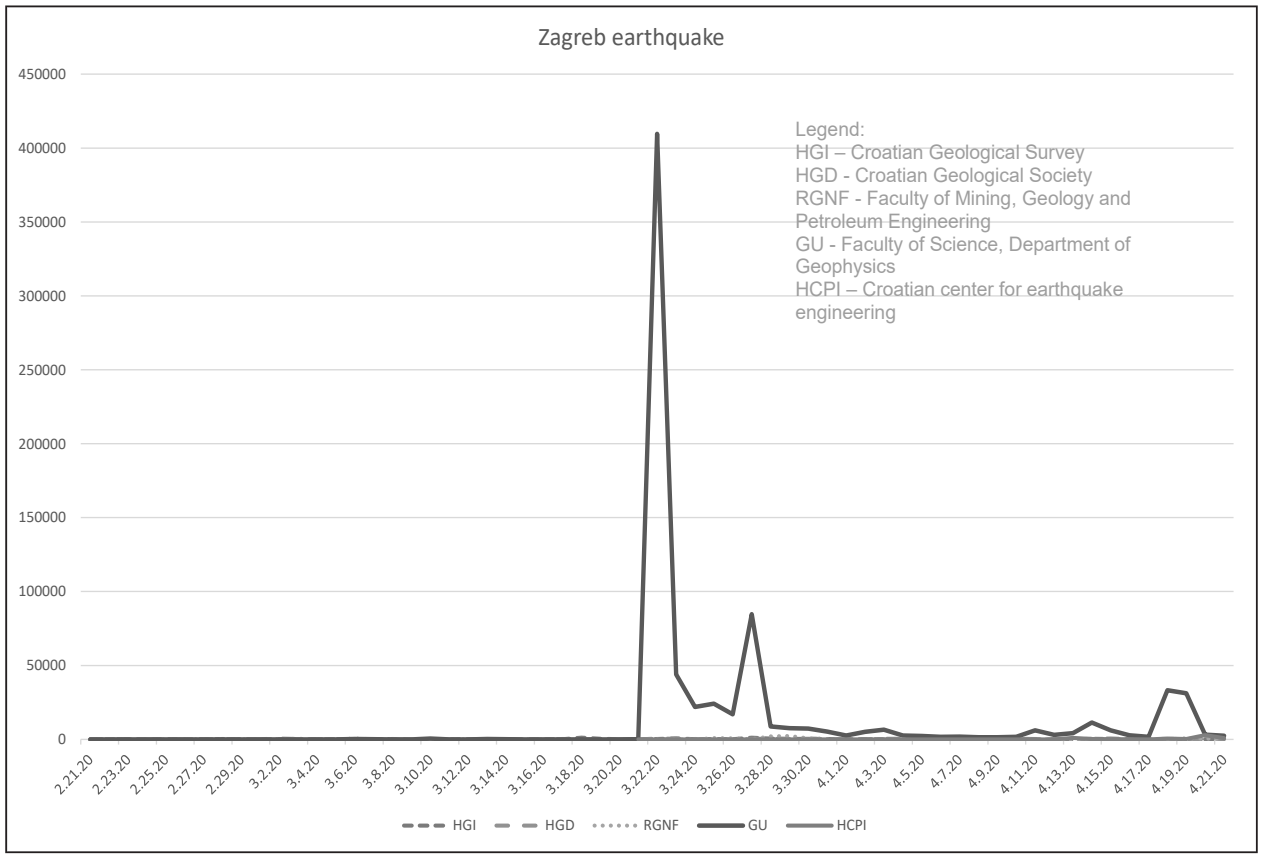

On the other hand, the frequency of visits to the Department of Geophysics website was significantly lower at the time of the Petrinja earthquake compared to the previous time period (Fig. 3), possibly because a large number of citizens installed an earthquake monitoring application by that time. Nevertheless, in the post-earthquake period the number of visits to all analysed institutions' Facebook pages increased. We assume that the increase of interest is due to more obvious and long-term consequences, such as the opening of collapsing sinkholes, liquefaction, and other. 
Figure 3.

Number of visits to Facebook pages of relevant institutions in the month before, and after the Petrinja earthquake. Note the number of visits on the vertical axis.

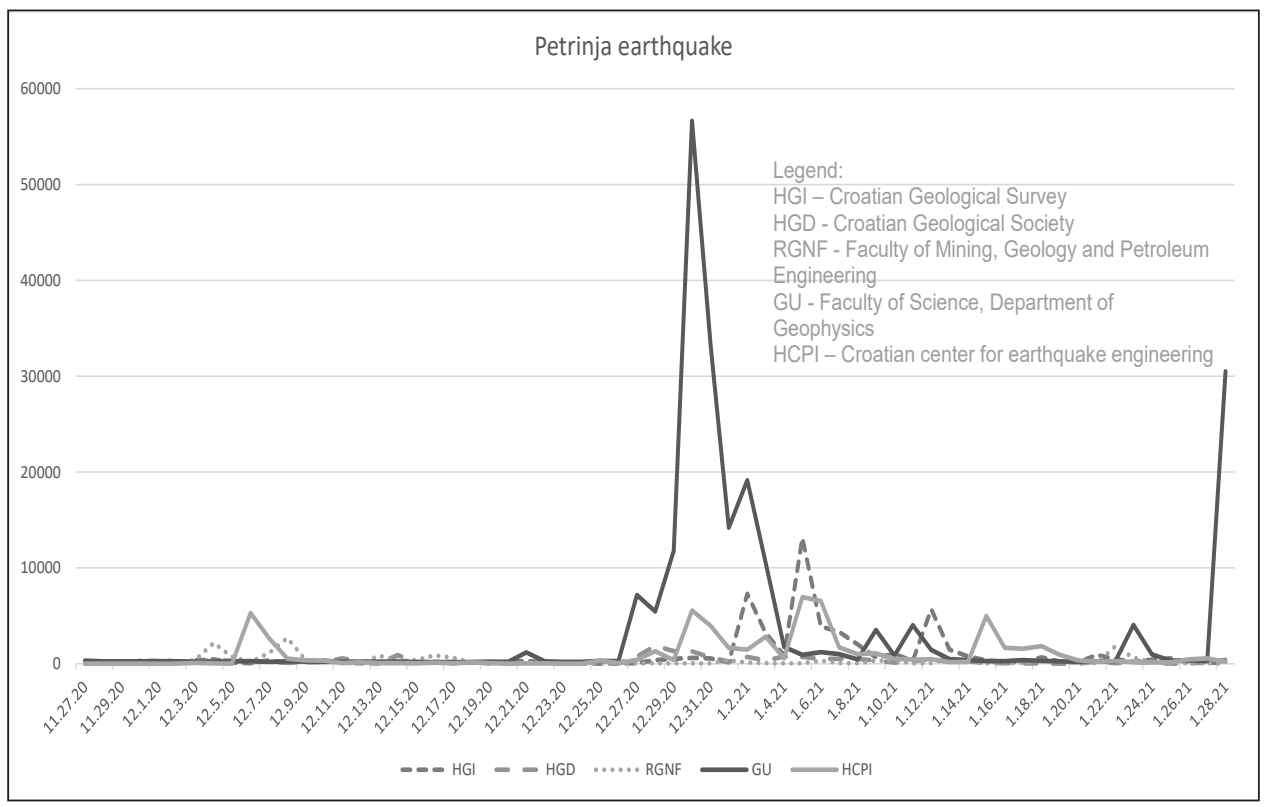

From the performed analysis we can conclude that the frequency of visits to Facebook pages is higher than the frequency of visits to the official web pages. This is partially influenced by the fact that more information was shared on social media. In addition to sharing posts from the official website, posts from other sites and portals have been shared on social networks.

It can also be noticed that after the Zagreb earthquake the interest in seismological and geological information increased and most of the pages recorded a steadily higher traffic. The trend of attendance continued even before the Petrinja earthquake, although the announcements were not related to earthquakes. Of course, as it could be expected, due to a great number of post-earthquake geological phenomena, the longterm interest was much higher after the devastating Petrinja earthquake (Fig. 3). This is also related to the official announcements for the public and the increased interest of other media.

\section{Content analysis results and discussion}

Most of the published content falls into the category of Additional Information that provides a more detailed insight into the crisis event(s) and informs the public about relevant facts. The language is simplified and adapted to the target group. 


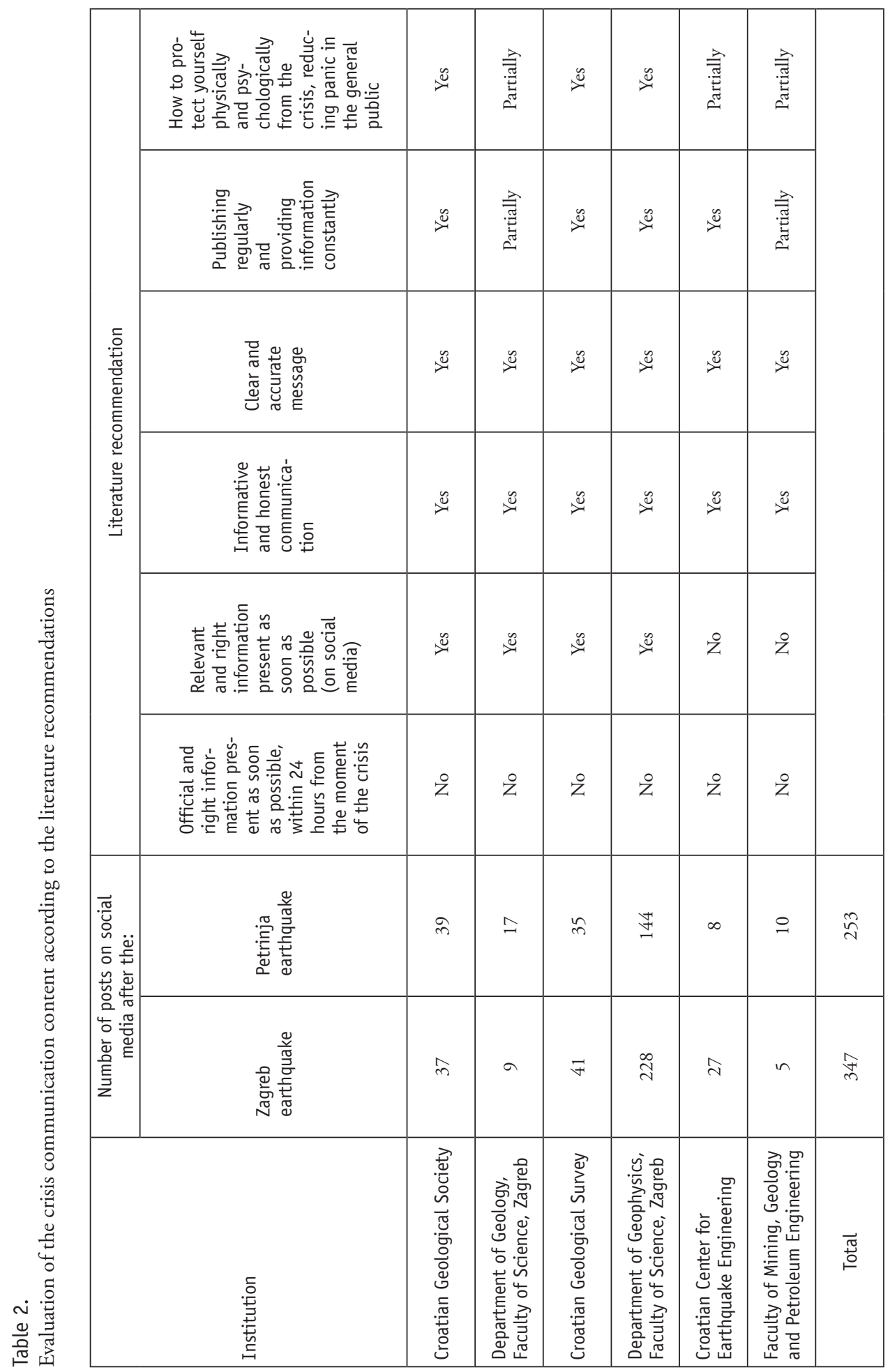


Given the target audience, the vast majority of the published content is aiming at the general population. Only a handful of the published content (content that is categorized as official report or more detailed information) is intended for the media, but this content is also essentially intended for the general population. The number of published posts aimed exclusively at the academic community is negligible; this kind of content targets students affected by the earthquake, or is about informing the academic community about the conducted scientific research, invitations to workshops, other events, etc.

Regarding the regularity of publishing the content and providing information on a constant level, for the purposes of this analysis, regularly published content is considered to be an up-to-date post, i.e. the publication of information within a reasonable time from the occurrence of the event. In this sense, almost all institutions behaved uniformly: they reacted on social media channels on the day of the earthquake hit, while the official press release came a few days later, after the information was already placed in the media. In today's age of the Internet and social networks, the media starts reporting on natural disasters just after they occur. It is quite understandable that institutions cannot publish more detailed information at the same time they happen, but it is recommended to react (publish more detailed and official information) within 24 hours of the event for the following reason: in the absence of verified information, the media often publishes unverified and unreliable content in order to attract attention of the audience, which can create a distorted picture of reality and upset the public. Having this in mind, the recommendation would be to cooperate with (especially local) media while reporting.

When looking at the mentioned institutions as a whole, in the first month after the earthquake(s), it is evident that the vast majority of content is related to the earthquake(s) and subsequent earthquakes. The number of earthquake-related published content slightly decreased over time, and non-earthquake related content is being published. Also, it can be seen that the social networks and the websites of the institutions (viewed as a whole) are partially harmonized. For example, some institutions have only official reports visible on their website, and there are no clear instructions on how to act properly if the earthquake hits, while all those information can be found on their social media channels. It can also be seen in Table 2 that all institutions posted more often on social networks than on their websites.

On the other hand, if looking at the relevant institutions individually, the Department of Geophysics has much greater activity and more detailed reports, which is not surprising since seismology is a branch of geophysics where the causes and properties of earthquakes are investigated. Other institutions often shared the Department of Geophysics' content on their social media channels. In addition, the Department of Geophysics also created a relationship with their audience - they "listened" to stakehold- 
ers' questions and answered them, thus reassuring the public and reducing the panic, informing them and putting them first. Direct communication with the stakeholders has certain challenges, mostly related to determining which comments and questions are useful and should be taken into account. An increase in trust in the institution has been observed after giving information in regular time intervals and taking stakeholders' comments into account. The Department of Geophysics' website includes most details about the two earthquakes and how to behave in this "new situation". Two categories have been set up on their website: "About the Zagreb earthquake", and "Earthquakes near Petrinja“. A category "About earthquakes" has also been opened, where answers to the most frequently asked questions, more detailed explanations and information have been placed. This category was not significantly updated during the Petrinja earthquake, but it already contained important information that people were interested in after the Zagreb earthquake, so it was applicable in the case of Petrinja. The only literature recommendation that has not been followed completely is the advice of publishing an official report (in the form of an official press release) within 24 hours. A short report containing relevant seismological information about the event has been published on the Seismological Survey official website, in a standard form of communication for all earthquakes felt in the Republic of Croatia. Relevant information has been presented regularly and in a timely manner in new forms of short reports. This is a good example of crisis communication protocols designed for urgent population informing.

As seen in Table 2, the results of the Content Analysis indicate that certain recommendations from literature were followed by scientific and professional institutions. However, releasing official information (in the form of an official press release) about the earthquakes before it is reported in traditional or digital media is missing. Social media channels have proven to be a channel through which information can be sent quickly and efficiently, since today almost everyone uses social networks. It should be emphasized that, during the crisis, social media channels served as a primary communication channel that provided earthquake information from damaged areas directly. Social media provided two-way communication with the stakeholders and an excellent way of gathering information from the public. The amount of published content varies from institution to institution - each institution decides for itself what is relevant and important for them and their occupational area.

This analysis has some limitations: it is subjected to the author's interpretation, and it has not been established which sources of information stakeholders use while informing about earthquakes, and what type of information they demand. Given these limitations, future research should provide a clearer understanding of crisis communication during an earthquake by focusing on the relevant type and source of information. Furthermore, future research should expand the knowledge on crisis communication by focusing on the users' needs, i.e. what kind of information citizens search for during and after such crisis, what sources of information citizens consider reliable etc. 


\section{Conclusion and implications}

A review of scientific papers on the topic of crisis communication of scientific facts in times of natural disasters showed that this topic is significantly underestimated. Our research has shown that science can empower the public and responders through crisis communication to make better decisions, and to minimise the formation of rumours or inaccurate information getting out from unofficial and unreliable sources or social media.

Closing the gap between desired practice and current practice requires effective communication which is well recognized in crisis communication studies, but neglected in natural sciences. In this paper, we address how current communication practices of scientific institutions have been adapted during the two earthquakes. The earthquakes in Zagreb and Petrinja have shown that social media channels served as a primary communication channel through which earthquake information from the damaged areas was provided directly. Social media provided two-way communication with the stakeholders and an excellent way of gathering information from the public. Given the target group, the vast majority of the published content was aiming at the general population. Immediately after the earthquake, the number of visits to the Facebook pages of the analysed institutions (with an emphasis on the Seismological Survey at the Department of Geophysics) was growing significantly, indicating that people trust scientific institutions in times of crisis.

Our empirical data suggest that interactive communication that strives to address local contextual concerns, explain actions, and provide honest, timely, accurate and reliable information is most effective, as has been found in previous studies. It is, therefore, important to address existing issues in practice to achieve appropriate levels of crisis communication (Table 3).

Table 3.

Potentials for enhancing crisis communication

\begin{tabular}{|l|l|l|}
\hline \multicolumn{1}{|c|}{ Detected issue } & \multicolumn{1}{|c|}{ Possible improvements } & \multicolumn{1}{c|}{ Desired state } \\
\hline Delayed reaction & $\begin{array}{l}\text { Determining a protocol for } \\
\text { crisis situations communi- } \\
\text { cation } \\
\text { Sharing information from the } \\
\text { Seismological Survey }\end{array}$ & $\begin{array}{l}\text { Reaction within 24 hours of the } \\
\text { event }\end{array}$ \\
\hline $\begin{array}{l}\text { Non-existent analysis of visits by } \\
\text { institutions }\end{array}$ & - $\begin{array}{l}\text { Enabling monitoring tools } \\
\text { (Google analytics/Audit o) }\end{array}$ & $\begin{array}{l}\text { Incorporated analytics tools and } \\
\text { monthly reports }\end{array}$ \\
\hline
\end{tabular}




\begin{tabular}{|l|ll|l|}
\hline \multicolumn{1}{|c|}{ Detected issue } & \multicolumn{1}{|c|}{ Possible improvements } & Desired state \\
\hline Insufficient use of official websites & $\bullet$ & $\begin{array}{l}\text { Creating user-friendly sites } \\
\text { Forming a protocol for news } \\
\text { creation on websites }\end{array}$ & Up to date reporting on websites \\
\hline $\begin{array}{l}\text { Technically reliable website } \\
\text { creation }\end{array}$ & $\begin{array}{l}\text { Forming a press release team } \\
\text { towards media }\end{array}$ & $\begin{array}{l}\text { Forwarding inquiries on a } \\
\text { relevant interlocutor }\end{array}$ & Press releases page on website \\
\hline
\end{tabular}

Beyond the main issues detected in this research, we need to emphasize the positive and negative effects which arose from the studied crisis events. The negative effects can generally be explained through the unpreparedness of every institution (and person in general) to a crisis of this scale. Everybody had to manage in the best possible way, despite the difficulties that occurred (such as power outages that occurred after the earthquakes). The Seismological Survey was the first to react and give information about what had happened and how to behave. This was to be expected as they regularly cooperate with the Ministry of Interior Affairs, Civil Protection Service and some local authorities. Other institutions had to find a way to react or share their information to help in the crisis and needed more time to investigate the consequences of the events. Generally, most of the events connected with the studied crisis brought long term positive effects. The communication between different institutions (Faculty of Science, Croatian Center for Earthquake Engineering, Faculty of Mining, Geology and Petroleum Engineering, Croatian Geological Survey, Croatian Geological Society, and even Institute for Tourism) has been increased, which can be seen through a reciprocally shared content of other institutions, and especially data of the Seismological Survey. This practice needs to be continued, together with constant improvements of the data given on the websites of relevant institutions. These events revealed what can be improved for future events, what information was missing from certain institutions and what data needs to be collected in more detail. Furthermore, they opened new possibilities for research and projects dealing with earthquakes and their consequences. The media have been highly interested in these crisis events, which is a new possibility to engage scientists in discussions about different elements of natural disasters. In the future, this communication should be continuous, by sharing scientifically based information through media reports. Each institution should establish a protocol with determined steps in case of crisis (especially concerning natural disasters) as a part of their communication strategy, along with the assigned person (or team) that would be in charge for the communication with the media. This would enable all members of institutions to react with as little panic and fear as possible, and deal with the crisis in the best possible way. 


\section{Acknowledgements}

We thank our colleagues from University of Zagreb, Faculty of Mining, Geology and Petroleum Engineering; University of Zagreb, Faculty of Science, Department of Geophysics, Seismological Survey; University of Zagreb, Faculty of Science, Department of Geology; Croatian Geological Survey; Croatian Centre for Earthquake engineering and Croatian Geological Society for their website and Facebook page traffic data.

\section{References}

1. Alexander, D. E. (2010). The L'Aquila Earthquake of 6 April 2009 and Italian Government Policy on Disaster Response. Journal of Natural Resources Policy Research, 2 (4): 325-342. DOI: 10.1080/19390459.2010.511450.

2. Alexander, D. E. (2014). Communicating earthquake risk to the public: the trial of the "L'Aquila Seven". Natural Hazards, 72: 1159-1173. https://doi. org/10.1007/s11069-014-1062-2.

3. Benessia, A. and De Marchi, B. (2017). When the earth shakes... and science with it. The management and communication of uncertainty in the L'Aquila earthquake. Futures, 91: 35-45. https://doi.org/10.1016/j.futures.2016.11.011.

4. Bogdan, A. (2020). Najsnažniji potres u posljednjih 140 godina. Gradevinar, 72/4: 361-370.

5. Bulajić, M. (2010). Krizno komuniciranje. Medix, 16 (3): 87-88.

6. Cho, S. E.; Jung, K. and Park, H. W. (2013). Social Media Use during the 2011 Japan Earthquake: How Twitter Transforms the Locus of Crisis Communication. Media International Australia incorporating Culture and Policy, 149: 28-40.

7. Collins, M.; Neville, K.; Hynes W.; Madden, M. (2016). Communication in a disaster - the development of a crisis communication tool within the S-HELP project. Journal of Decision Systems, 25 (1): 160-170. https://doi.org/10.1080/1 2460125.2016.1187392.

8. Coombs, W. T. (2014). State of crisis communication: Evidence and the bleeding edge. Research Journal of the Institute for Public Relations, 1 (1): 1-12.

9. Croatian Standards Institute / Hrvatski zavod za norme (2011). HRN EN 1998-1:2011/NA:2011, Eurokod 8: Projektiranje potresne otpornosti konstrukcija - 1. dio: Opća pravila, potresna djelovanja i pravila za zgrade - Nacionalni dodatak.

10. Cutlip, S. M.; Center, A. H. and Broom, G. M. (2003). Odnosi s javnošću (Effective Public relations). Zagreb: MATE.

11. Čavalić, A. (2015). Crisis communication and the Internet, Conference proceedings: $4^{\text {th }}$ International Scientific Conference "Economy of Integration"ICEI, Tuzla. https://www.researchgate.net/publication/316601669_Crisis_communication and the Internet accessed February 11, 2021. 
12. Dasović, I.; Herak, D.; Herak, M.; Latečki H.; Mustać, M.; Tomljenović, B. (2020). O potresima u Hrvatskoj. Vijesti Hrvatskoga geološkog društva, 57/1: 4-27.

13. Herak, M.; Allegretti, I.; Herak, D.; Ivančić, I.; Kuk, V.; Marić, K.; Markušić, S.; Sović, I. (2011). Republika Hrvatska. Karta potresnih područja. http:Ilseizkarta.gfz.hr.

14. Ivančić, I.; Herak, D.; Herak, M.; Allegretti, I.; Fiket, T.; Kuk, K.; Markušić, S.; Prevolnik, S.; Sović, I.; Dasović, I.; Stipčević, J. (2018). Seismicity of Croatia in the period 2006-2015. Geofizika, 35/1: 69-98.

15. Marincioni, F.; Appiotti, F.; Ferretti, M.; Antinori, C.; Melonaro, P.; Pusceddu, A.; Oreficini-Rosi, R. (2012). Perception and Communication of Seismic Risk: The 6 April 2009 L'Aquila Earthquake Case Study. Earthquake Spectra, 28 (1): 159-183. doi:10.1193/1.3672928.

16. Markušić, S.; Stanko, D.; Korbar, T.; Belić, N.; Penava, D.; Kordić, B. (2020). The Zagreb (Croatia) M5.5 Earthquake on 22 March 2020. Geosciences, 10: 252. doi:10.3390/geosciences 10070252 .

17. McClusky, S.; Balassanian, S.; Barka, A.; Demir, C.; Ergintav, S.; Georgiev, I.; Gurkan, O.; Hamburger, M.; Hurst, K.; Kahle, H.; Kastens, K.; Kekelidze, G.; King, R.; Kotzev, V.; Lenk, O.; Mahmoud, S.; Mishin, A.; Nadariya, M.; Ouzounis, A.; Paradissis, D.; Peter, Y.; Prilepin, M.; Reilinger, R.; Sanli, I.; Seeger, H.; Tealeb, A.; Toksöz, M. N.; Veis, G. (2000). Global Positioning System constraints on plate kinematics and dynamics in the eastern Mediterranean and Caucasus. Journal of Geophysical Research, 105 (B3): 5695-5719.

18. Mirosavljević, M. (2010). Odnosi s javnošću. Banja Luka: Banja Luka CollegeBesjeda Banja Luka.

19. Mohorovičić, A. (1910). Potres od 8. X 1909. Godišnje izvješće Zagrebačkog meteorološkog opservatorija za godinu 1909, 9/4: 1-56.

20. Perez-Lugo, M. (2004). Media Uses in Disaster Situations: A New Focus on the Impact Phase. Sociological Inquiry, 74: 210-225.

21. Puška, A. and Maksimović., A. (2014). Odnosi s javnošću putem internetskih stranica na primjeru krizne situacije u mliječnoj industriji. Praktični menadžment, 5 (1): 92-97.

22. Sawalha, I. H. (2020). A contemporary perspective on the disaster management cycle. Foresight, 22 (4): 469-482. https://doi.org/10.1108/FS-11-2019-0097.

23. Sellnow, D.; Iverson, J. and Sellnow, T. L. (2017). The evolution of the operational earthquake forecasting community of practice: the L'Aquila communication crisis as a triggering event for organizational renewal. Journal of Applied Communication Research, 45/2: 121-139. DOI: 10.1080/00909882.2017.1288295.

24. Sturges, D. L. (1994). Communicating through crisis: A strategy for organizational survival. Management Communication Quarterly, 7 (3): 297-316. https:// doi.org/10.1177/0893318994007003004.

25. Steelman, T. A. and McCaffrey, S. (2013). Best practices in risk and crisis communication: Implications for natural hazards management. Nat Hazards, 65 (1): 683-705. https://doi.org/10.1007/s11069-012-0386-z. 
26. Šavor Novak, M.; Uroš, M.; Atalić, J.; Herak, M.; Demšić, M.; Baniček, M.; Lazarević, D.; Bijelić, N.; Crnogorac, M. and Todorić, M. (2020). Zagreb Earthquake of 22 March 2020 - Preliminary Report on Seismologic Aspects and Damage to Buildings. Gradjevinar, 72 (10): 843-867. https://doi.org/10.14256/ ICE.2966.2020.

27. Tekeli-Yesil, S.; Kaya, M. and Tanner, M. (2019). The role of the print media in earthquake risk communication: Information available between 1996 and 2014 in Turkish newspapers. International Journal of Disaster Risk Reduction, 33: 284289. https://doi.org/10.1016/j.ijdrr.2018.10.014.

28. Weber, J.; Vrabec, M.; Pavlovčič-Prešeren, P.; Dixon, T.; Jiang, Y.; Stopar, B. (2010). GPS-derived motion of the Adriatic microplate from Istria Peninsula and Po Plain sites, and geodynamic implications. Tectonophysics, 483: 214-222. 


\title{
Važnost znanstveno utemeljenih činjenica u kriznom komuniciranju: Dokazi iz zagrebačkog i petrinjskog potresa
}

\author{
Izidora Marković Vukadin \\ Institut za turizam, Zagreb, Hrvatska \\ e-mail: izidora.markovic@iztzg.hr
}

Marija Mustá́

Sveučilište u Zagrebu, Prirodoslovno-matematički fakultet, Geofizički odsjek, Seizmološka služba, Hrvatska e-mail: marija.mustac@gfz.hr

\section{Lidija Nujić}

Institut za turizam, Zagreb, Hrvatska

e-mail: lidija.nujic@iztzg.hr

\section{Karmen Fio Firi}

Sveučilište u Zagrebu, Prirodoslovno-matematički fakultet, Geološki odsjek, Hrvatska e-mail: karmen.fio@geol.pmf.unizg.hr

\section{Jasminka Martinjak}

Hrvatski geološki institut, Zagreb, Hrvatska

e-mail: jasminka.martinjak@hgi-cgs.hr

\section{Zrinka Marušić}

Institut za turizam, Zagreb, Hrvatska

e-mail: zrinka.marusic@iztzg.hr

\section{Maja Baniček}

Sveučilište u Zagrebu, Građevinski fakultet, Hrvatska

e-mail:maja.banicek@grad.unizg.hr

\section{Sažetak}

Potresi su prirodni fenomeni koji mogu snažno utjecati na zajednice, infrastrukturu i okoliš. Hrvatska je dio tektonski i seizmički aktivnog područja, tako da bi njezini stanovnici i nadležne institucije trebali biti svjesni mogućih opasnih događaja, koji mogu biti razorni. Stoga je krizna komunikacija izuzetno važna, a u slučaju prirodnih katastrofa poput potresa mora biti jasna, pravodobna i sažeta. Znanstvene institucije koje se bave potresima također bi trebale biti uključene u krizno komuniciranje. Podaci o dva snažna potresa 2020. godine koji su potresli područje Zagreba i Petrinje te širu okolicu, pokazali su kako se relevantne institucije mogu nositi s informacijama o potresima i njihovim posljedicama i javno ih dijeliti. Ovaj rad usvaja mješoviti dizajn istraživanja, kombinirajući i kvalitativne i kvantitativne podatke o potresima u Zagrebu i Petrinji iz različitih izvora znanstvenih i stručnih institucija iz područja geologije, geofizike, seizmologije i građevinarstva u Hrvatskoj. Empirijski podaci sugeriraju da je najučinkovitija interaktivna komunikacija koja nastoji riješiti lokalne kontekstualne probleme, objasniti radnje i pružiti iskrene, pravodobne, točne i pouzdane informacije. Ubuduće institucije moraju pronaći način da reagiraju ili podijeliti svoje informacije kako bi pomogle u krizi.

Ključne riječi: potresi, društveni mediji, analiza sadržaja, krizna komunikacija. 